\title{
Evaluating the Marketing Communication Strategy of Volkswagen in Post-Crisis Period: Application of Image Repair Theory
}

\author{
Almoatazbillah S. Hassan ${ }^{1}$ \\ ${ }^{1}$ The York Management School, University of York, York, United Kingdom \\ Correspondence: Almoatazbillah Hassan, The York Management School, Freboys Lane, University of York, \\ Heslington, York, YO10 5GD, UK. E-mail: ash525@york.ac.uk
}

Received: February 9, 2019 Accepted: March 4, $2019 \quad$ Online Published: May 21, 2019

doi:10.5539/ijms.v11n2p87 URL: https://doi.org/10.5539/ijms.v11n2p87

\begin{abstract}
This case study focuses on effective marketing communication activities in a post-crisis period. The phenomenon underpinning the investigation is image repair theory which provides effective communication strategies to overcome these events. The case in point was the emission scandal faced by Volkswagen (VW) in 2015. By implementing a qualitative approach to data collection and analysis, the results showed some correlations between effective public relation activities and the company's share price. Nevertheless, sales figures showed a negative attribute due to the unstable position of the company in the post scandal period. Results also showed a positive pattern when VW responded to the emission scandal in the early days, providing some strategies to stakeholders such as, mortification, reducing offensiveness and corrective action. However, it can be said that this study is an initial step which provides some indications for future research concerning the effective implementation of marketing communication in a post-scandal period.
\end{abstract}

Keywords: corporate scandal, corporate crisis, crisis communication, post-crisis marketing communication, image repair theory

\section{Introduction}

Volkswagen (VW) - the German car manufacturer - had an unfortunate time due to its diesel car emission test failure in September, 2015. The company is home to 12 well-known car brands, such as, Audi, Seat, Porsche, Skoda and Volkswagen. The full story began on 18th September 2015 when the Environmental Protection Agency in the USA issued a statement of valuation against the company. Several days later, the Chief Executive Officer (CEO), Martin Winterkorn, resigned. On September the 22nd the company admitted that there were 11 million cars worldwide which had been fitted with a defective part. The company was ordered to recall the affected cars and they initially put aside $£ 4.5$ billion ( $\$ 5.9$ billion) to deal with the problem (Ruddick, 2015). In June 2016, the authority decision in the USA was made and the amount was forecast to increase to $\$ 15$ billion. As a result, this had a noticeable impact on the company's share price as well as sales. According to Bloomberg.com (2015), the share price of VW fell sharply by almost $23 \%$ in the day after the emission scandal broke. In addition, sales reports showed at least a 5.4\% drop in the month following the scandal (Kottasova, 2015).

Corporate scandals/crises have become more common these days because of the speed of production. Berman (1999) suggested that it is only a matter of time before a manufacturer has a defective product which leads to a product recall. Companies must respond to these events effectively and efficiently. VW began with major changes to its managerial team starting with the CEO and the public relations manager. The company had definitely planned how to face this event to reduce the impact on stakeholders. These stakeholders are mainly, customers, investors, retailers and manufacturers. They started to implement their communication plan to reduce the damage to the brand by planning and executing several marketing communication activities to respond to the scandal and to regain the lost trust, for instance, press releases, TV advertisements, announcements of product development and brand development activities.

This is a qualitative case study to assess the effectiveness of some of VW's marketing communication activities after the scandal. The phenomenon used to examine this is the image repair theory which combines most of the strategies which an individual or an organisation would employ in a post-crisis period (Benoit, 2014). The process of selecting which publication to include in this study was very specific. It was decided to include all 
stakeholders' press releases between September 2015 and June 2016, as long as they featured the scandal and its consequences. The purpose of this study is to link VW's communication strategy to strategies in the image repair theory. In addition, it will also evaluate the effectiveness of VW's communication activities in the post-scandal period. Moreover, it will address the usefulness of employing strategies from the image repair theory in a real-world example.

\subsection{Research Aim and Questions}

The aim of this study is to evaluate the effectiveness of the marketing communication strategy which was used by VW throughout the post-emission scandal period based on the image repair theory. Four research questions (RQ) were set, these are:

RQ1. What was the marketing communication strategy that was used by VW in response to the emission scandal? How is it linked to the theory of image repair?

RQ2. Based on the official monthly published sales reports and the share price of the company, is the strategy having any impact on stakeholders' perceptions of the company?

RQ3. What are the advantages and disadvantages of applying communication strategies from the perspective of image repair theory?

RQ4. What changes could VW employ in its communication strategy in order to regain stakeholders' trust? Can any positive lessons be learnt from VW's application of the communication strategy?

\section{Literature Review}

\subsection{Corporate Scandal and Corporate Crisis}

Corporate scandal and corporate crisis are those events which all companies work hard to avoid in order to protect their reputation. An organisation's reputation is considered a valued resource that it preserves at all cost (Coombs \& Holladay, 2002). Corporate reputation is regarded as the most valuable asset which contributes greatly to an organisation's success (Hall, 1992; Tischer \& Hildebrandt, 2014). Walsh et al. (2009) define corporate reputation as a combination of all aspects which are well known and already perceived by all stakeholders who deal with the organisation. Corporate scandal and corporate crisis are different due to the reasons that lay behind them but they have almost the same consequences. In this study the concerns are related to the consequences rather than the causes. These consequences are mainly product recall, investors' loss of trust, negative impact on the brand, the cost of legal aspects, and the cost of corrective actions (Jory et al., 2015; Hsu \& Lawrence, 2015). Corporate scandal refers to the action of committing what is prohibited under the role of good governance (Jory et al., 2015). On the other hand, corporate crisis is concerned more with the unexpected and the non-routine events that create a level of uncertainty and impact negatively on the organisation's performance (Coombs, 2012; Seeger et al., 2003).

The negative impact of a corporate scandal or crisis can be serious. These unfortunate events usually harm the relationship between an organisation on one side and both customers and investors on the other. Heath and Millar (2004) stated that a crisis is an untimely event which has perceived consequences for stakeholders' interests and for the reputation of the organisation. From the customers' perspective, a corporate crisis has serious consequences at the level at which customers accept the brand and the product in the future. Helm and Tolsdorf (2013) state that a corporate crisis could be the most influential factor in decreasing the level of 'brand loyalty'. According to The American Marketing Association, brand loyalty is the dedication to buying a product or service repeatedly regardless of competitor's actions. However, it is difficult to retain this relationship in a crisis period. Cleeren et al. (2008) state that it is likely that the brand might lose $15 \%$ of its customers during a product recall period. In addition, Dutta and Pullig (2011) concluded their pilot study into consumers' loyalty and equity towards a brand in a post-crisis period by indicating that the brand is perceived negatively by consumers during the post-crisis period.

On the other hand, investors are likely to try to avoid crisis as they cause uncertainties in relation to their investments. Crises usually have negative impacts on share prices, progress of development plan, and the cost of recall which ultimately affects the net profit and the profit per share gained by investors. Jory et al. (2015) examined major scandals in the US which affected the public between 1993 and 2011. They found that, investors react adversely to corporate scandals, however, this reaction varies depending on the company's cash flow ability. For instance, those companies who have significant cash resources are more likely to overcome the consequences of the scandal compared to those who have less cash. In addition, when unethical actions occur all stakeholders, especially investors, are doubtful about the company's ability to continue to meet its fiduciary 
responsibility. Consequently, their share values and profits are expected to fall for a long period (Long \& Rao, 1995).

When a crisis hits, a company is required to respond effectively and to avoid any uncertainty. The response to the corporate scandal should match the nature of the crisis (Dutta \& Pullig, 2011). In addition, it is suggested that the company responds to a crisis based on its customers' perspectives (Laufer \& Coombs, 2006). Although it is crucial to use advertisements as a technique to overcome a crisis, the most important issue is the selection of the target segment (Kim \& Atkinson, 2014). Moreover, Dawar and Pillutla (2000), stress the importance of utilising social media tools in responding to a scandal. Many channels and strategies can be employed to overcome such a threatening event but the question is how to plan and implement them effectively.

\subsection{Marketing Communication}

The role of marketing communication is vital when planning strategies to broadcast a company's values, products, and activities. It is very important for an organisation to plan and implement a proper marketing strategy in all stages of its life; starting from building their identity, communicating their values, publicizing their social responsibilities activities, to new product/service announcements and so on (Fill, 2013). Communication then becomes more important for a company either during or after a period of corporate scandal or a crisis, as it helps in preventing or minimising the level of damage that these events may cause to the reputation of the organisation (Ulmer et al., 2013).

Both marketing communication and crisis communication are correlated in some of their objectives, audiences, tools, message types and responses. Crisis communication refers to the effect that a company intended to have upon its stakeholders' perceptions of the crisis (Coombs, 2015). There are two main strategies to consider in crisis communication: (1) Managing information which involves the collection and spread of the information related to the crisis. (2) Managing meanings which refers to the efforts involved in influencing the perception of the crisis by people and/or the extent to which the company's involvement in this crisis (Coombs \& Holladay, 2011). Fill (2013) stressed the importance of the prior planning of crisis communication and the need to assess an organisation's vulnerabilities at the earliest opportunity.

Every communication plan includes one or more activities which use at least one communication tool that focuses on responding to the crisis. According to Kim (2013) corporate communication activities include public relations, corporate advertising, social responsibility activities and sponsorships and so forth. Corporate advertising is an important component of the marketing communication plan in an organisation which focuses on enhancing the organisational reputation and visibility within the environment that the company operates in. In addition, it helps in protecting the company's image during a crisis period by maintaining a positive attitude towards the company (Ho et al., 2016). Both corporate advertising and public relations are considered the main activities in delivering wide-reaching messages to audiences.

Marketing communication uses a wide range of tools. The selection of each tool is based on the objective of each message. For marketing communication in a post crisis period it is strongly suggested that a company implement a proper presentation of the brand which does not damage the reputation (Dutta \& Pullig, 2011). Apart from brand equity and integrated marketing communication strategies, it is also important to use advertisements as a strategy to overcome this event (Ho et al., 2016). In addition, the implementation of the social media tool is also necessary, especially these days, to spread the message more widely (Hsu \& Lawrence 2015).

\subsection{Steps of Crisis Communication}

Effective media plans and public relations activities are vital in business communication before the crisis occurs. A good plan for an organisation's communication activities should reduce the impact of the crisis on its stakeholders (Valackiene, 2010). Bernstein (2004) identified 10 steps in effective crisis communication, the first seven must be implemented before the crisis occurs, which means that a company must be prepared for any unfortunate events. These steps are: (1) formulate a crisis communication team, (2) identify a spokesperson, (3) provide appropriate training for the spokesperson, (4) establish a notification system, (5) identify your stakeholders, (6) anticipate crises by planning best and worst case scenarios, (7) develop holding statements, (8) assess the crisis situation, which is the first step which cannot be taken in advance, (9) identify key messages which have the best impact on the stakeholders in the post-crisis period, (10) ride out the storm by questioning whether the communication is making some changes or not and what other action is required to achieve a better results.

\subsection{Image Repair Theory}

The idea of image repair (restoration) theory came originally from concepts such as apologies (rhetorical studies), 
excuses and accounts used in sociological studies (Benoit, 2014). The term apologia refers to the defence or justification of an opinion or position (Pearse, 2010). Excuses always relate to emotions and are used when an individual or an organisation admits to wrongdoing and says 'sorry' (Gardner, 2009). Finally, the term accounts refers to a statement made by an organisation or an individual to justify or explain unanticipated or untoward behaviour (Scott \& Lyman, 1968). Recently, Benoit (2014) renamed the theory image repair discourse. Following this rationale, in order to restore the broken image, it is enough to repair the damage. In addition, persuasive defence usually succeeds partly in repairing the damaged image.

Image repair theory usually comes first when evaluating the effectiveness of any communication activity especially communications during crises. Benoit (1997) argues that the theory offers a corporation choices in what to say when facing a crisis. In addition, it is more exhaustive than the theory of apologia and accounts. Benoit (1995) identifies five strategies which an organisation or an individual can employ to repair a damaged image in a post-crisis period in an event where the reputation is affected. Frank and Michel (2009) state that the theory has become a central paradigm when examining a communication strategy during a crisis. The theory is based on two main assumptions, firstly, that every communication strategy is set to achieve a specific goal, and secondly, by achieving this goal an organisation or an individual should be able to restore their positive reputation and image. In addition, image repair strategy is based on two main components, (1) the accused is held responsible for the act, and (2) the act is described as offensive (Benoit \& Czerwinski, 1997). The five strategies of image restoration theory are discussed briefly below as they are addressed by Benoit and Czerwinski (1997):

Firstly, denial, which is to deny committing the offensive action. It can be formed into two different variants. One is simply to deny the act, which means that the accused claims they did not commit any wrongdoing. The other strategy is to shift the blame to someone else and that might be, for instance, one of its own departments or divisions. Both strategies are considered to be denial but the impact of each one is different and obviously the receivers of the messages also would be different in their level of affect.

Secondly, evasion of responsibility, which refers to not taking responsibility for the wrong action. This strategy consists of four different types. (1) Provocation, which happens when the offensive act was a response to another act which happened that the company has no power over. For example, a change in policy by a government could lead the company to change some manufacturing materials. (2) Defeasibility, which refers to a lack of given information or ability. For example, if the organisation has not been informed of the new regulations if there were any. (3) Accident, which refers to claiming the act was accused accidentally. If the organisation was successful in expressing this, it could reduce the damage to the company's image considerably. (4) Good intention, which means that the individual or an organisation have committed the offensive action with good intention.

Thirdly, reducing the offensiveness of the event which is to reduce the act's perceived offensiveness. This strategy has six different versions which can be applied. (1) Bolstering, which refers to the act of expressing the good traits that the company had in the past. This will help in strengthening the audience's positive feelings towards the company and balance the offensive act and the previous positive characteristics that the company held. (2) Minimisation, which refers to minimising the negative feelings associated with the offensive act. This could happen by reducing the seriousness of the act. (3) Differentiation, which refers to distinguishing between the act and other offensive ones, although if the act is considered negatively with less offensiveness. The company here tries to reduce the offensiveness by comparing the act with any similar event and highlighting the other one as more damaging compared to the case in hand. (4) Transcendence, which is the attempt to place the act in a less offensive frame and in a more favourable context. (5) The attack of accuser, this refers to those who are blamed for something negatively beginning to counter-attack the accuser with the aim of reducing their credibility. (6) Compensation, is the last form of reducing offensiveness. Usually compensation works very effectively in improving the image reputation of the organisation but indeed it is a very costly strategy.

Fourthly, corrective actions, which refers to any promises to correct the problem. This could also include promises to prevent any future faults. Finally, mortification, which is to show a high level of embarrassment and shame in which one could admit guilt and express regret.

Although Image Restoration Theory covers almost all strategies that an organisation or an individual may consider in repairing a negatively affected reputation, it also has some limitations. Holtzhausen and Roberts (2009), argue that the theory remains problematic and one of its weaknesses is the difficulty or even impossibility of linking between strategies used in the news published related to the crisis and with those strategies that the company planned. In addition, Coombs and Schmidt (2000) argue that, image repair theory is 
primarily descriptive and it is only a tool for identifying which strategy was used in a given situation. Therefore, it is must to be careful when analysing and interpreting results of case studies related to image repair theory.

\subsection{Association of Image Repair Theory and Corporate Scandal}

Benoit (1997) tested some of the image repair theory's strategies in the case of USAir after the tragedy of the air jet crash in September 1994 near Pittsburgh, when 132 passengers were killed. This accident had a negative impact on the airline's reputation as well as an economic one. Most of the newspapers at that time criticised the company's safety regulations. Benoit studied the way that USAir responded to the crisis in comparison with two different cases which happened with two other large organisations in the USA. He concluded that the theory of image repair discourse does not provide a complete approach to communication during a crisis. However, it provides more insight into the preparation of persuasive messages. Moreover, it was found that when a company is at fault, it is more persuasive to admit the offensive action and apologise rather than try to avoid responsibility. In addition, Benoit emphasised that corrective actions are one of the most important components of the image repair. He maintained that USAir was least effective in this regard as the company refused to admit any fault and attempted to avoid any cost for the corrective actions.

Another study by Harlow et al. (2011) applied the theory of image repair to British Petroleum's (BP) spill in the Gulf of Louisiana. The company faced a large amount of criticism from the public for damaging the environment, in addition to the substantial damage to its financial status. The company quickly attempted to apply some strategies of the image repair theory. The study concluded that the theory provides useful strategies in how to respond in the initial stages of a crisis. They also emphasised that the company worked effectively in correcting the problem and in compensating the victims. However, the company shows less intentions in their attempt to shift the blame or even to share responsibility with other corporations which were working in the same field. The study summed up by stating that it is hard to tell if BP's initial attempt to apply image repair theory was successful. However, it was also impossible to provide an ideal strategy in that short period (considering early days of the crisis). They suggested that results would be clearer in the long-term. Harlow et al. (2011) pointed out some significant tension in BP's response to the crisis. The company accepted the responsibility for cleaning up the damage and for compensating victims. However, their response to the public was to completely deny responsibility for the action. They assumed that there might be significant public relations ground to be gained by applying the mortification strategy.

A further study conducted by Holtzhausen and Roberts (2009) investigated the effectiveness of image repair theory in crisis management following content analysis of news published about sexual assaults at the U.S. Air Force Academy in 2002. Their findings showed that crisis management and image repair theory are a dialectic process. In addition, several situational factors such as, reputation of the organisation and involvement of politics and legislators are indications of the difficulty in predicting the most effective strategy to employ from image repair theory. Moreover, the study overwhelmingly stressed the importance of taking a proactive or balanced approach in the news rather than being reactive. Finally, the study pointed to an important issue which is the time in which an organisation must react to the news before new stories become public. Regardless of whether this news is right or wrong, audiences should have stories and clarifications from both sides.

\section{Research Methodology}

\subsection{Research Method}

The method used in this research takes an inductive approach to theory. Data were collected in advance from both primary and secondary sources and then linked to the theory of image repair. An inductive approach refers to the process of collecting data and then inducing the theory. This approach is argued to be the most appropriate for case study research and it is particularly evident in grounded theory (Bryman \& Bell, 2015, p. 25). Grounded theory helps in developing theory from data (Bryman \& Bell, 2015, p. 584). A case study design was used as this research focuses on the association between the effective implementation of image repair theory strategies to crisis communication. The case in hand is Volkswagen's emission scandal. A case study is an empirical enquiry which investigates a contemporary phenomenon in-depth within its actual context (Yin, 2013). In addition, qualitative strategy for data collection and analysis was used which emphasises textual and visual data.

The field of crisis communication is largely dominated by case studies (Coombs, 2007). This has helped in evaluating the effectiveness of the communication strategies which were adopted by VW in response to the emission scandal. The challenge of this case study was to collect and interpret the data logically and fairly. This is due to the subjectivist stance which has been considered. The process was used to collect the most influential messages in the post-emission scandal period. This in itself has some issues in regard to reliability of the data because the researcher has an influence on selecting and analysing them. However, another strategy was 
identified in order to raise the level of accuracy in these data which is triangulation of data (more details will be provided in the next part 3.4.3). Triangulation helps in determining the consistency of the findings (Ritchie et al., 2014; Yin, 2013). A combination of primary and secondary data was collected namely: press releases, sales figures, stock price charts, and an interview with a manager of a VW new car showroom in the United Kingdom.

\subsection{Data Collection}

Mainly secondary data was collected, which related to sales figures, share price charts and reports. The sources of the information were mainly derived from the published communication activities undertaken by VW in the post-scandal period. These activities included: advertisements, press releases, the 2015 annual report, monthly sales reports, and share price charts, mainly reports from Bloomberg.com. In addition, an interview was conducted with a manager of a VW new car showroom in the North of the United Kingdom. The reason for conducting the interview was to improve the accuracy of the results which came out of the analysis of the visual and written content.

Below is a list of the most significant textual and visual publications related to the VW scandal in the post-scandal period:

1) On 20th of September, 2015 the former CEO of VW revealed the findings of the US Environmental Protection Agency as they detected some manipulation of VW's diesel cars emission test.

2) Two days later, on 22nd of September, 2015 the company released an ad hoc press release about several engines which had been installed with the defective part. The company also stressed the urgency of the investigation and the level of importance that they attached to their customers' trust.

3) On 23rd of September, 2015 the former CEO, Professor Martin Winterkorn, announced his resignation and accepted responsibility for any irregularities which had taken place regarding the emission issue.

4) Several hours later, the board of executives announced the outcomes of the urgent meeting concerning the resignation of Professor Winterkorn as well as the emission issue.

5) Matthias Müller, the new CEO who was appointed on the 25th of October 2015, gave a speech at a company meeting on the 6th of October, 2015. He began his speech with this phrase "We will overcome this crisis". He clarified the emission scandal status, he stressed that the company would stand for good and secure jobs (targeting the employees), and he promised that a further review of the original strategic plans was to be carried out.

6) On the 10th of October, 2015 the company started a campaign called "We have broken the most important part of our cars: your trust". The campaign was mainly targeting the affected consumers with a promise to solve their problems and to assure there will be no drawbacks to their vehicles until the issue is solved.

7) As part of their marketing communication plan, VW published a one-minute YouTube advert which was entitled by "companion". The main intention of the advert was to emphasise the level of attachment between VW and its consumers at all stages of their life. The advert was released on the 3rd of February 2016 and it is available in this link: (https://www.youtube.com/watch?v=7BJpq61ArPw).

8) On the 3rd of November 2015, the CEO announced the initial results of the emission issue investigation. It included the number of affected cars, which was around 800,000. It also gave the cost related to repairing these cars which was set at approximately 2 billion euros.

9) By the 9th of December 2015 the company announced that the case of emission scandal had largely been concluded. They had identified the cars with the defective parts but stated that a higher number of cars than announced earlier were affected. The statement signalled the end to their internal investigation into the issue.

10) On the 28th of April 2016, Volkswagen published its 2015 annual report showing a steady financial performance. The report included the CEO Matthias Muller's message to all stakeholders in addition to highlighting the impact of the emission scandal and the company's strategy to overcome this unfortunate event.

11) By the 22nd of June 2016, the CEO of the company announced the launch of the biggest strategic change in the company's history. The strategy is for the next decade with objectives to become a model organisation as a modern, integral and legal affairs transparent firm.

12) On the 28th of June 2016 the company announced it had reached a settlement with the US authorities to pay around $\$ 14.7$ billion in compensation. The payment included all fines and penalties to the legal authorities, in addition to the recall expenses. 


\subsection{Data Analysis}

Considering all data types collected for this study, three different techniques were used to analyse the data. Firstly, analysing the semi-structured interview: mainly a thematic analysis technique was applied by using three different themes before conducting the interview which were: VW scandal's overview, customers' perceptions and the impact of the marketing communication activities held by the company in the post-crisis period. Bryman and Bell $(2015$, p. 481$)$ state that in semi-structured interviews, the researcher is prepared with a list of topics which are to be covered. My assumption before the interview was that the marketing communication activities that VW did, helped in protecting the company's image but not in overcoming the crisis. The choice of this type of interview was based on the objective of obtaining extensive information related to the impact of the marketing communication activities after the scandal. For interview analysis a thematic analysis technique was implemented according to the process of grounded theory. Thematic analysis is the process of extracting key themes from the data provided by interviewees (Bryman \& Bell, 2015, p. 729). The main goal of this interview is to obtain a view point from a practitioner and to triangulate the response with the secondary data mentioned above to improve its accuracy.

Secondly, when analysing of the written publications, a thematic categories technique was used. Listing five categories based on the image repair strategies, namely, denial, evasion of responsibility, reducing the offensiveness, corrective action and mortification. Each written text was tested among all five strategies, in order to establish if the text had one or more strategies applied to it. Thematic categories refer to a specific content such as a topic in a passage that contains any information related to the categories identified earlier (Kuckartz, 2014). These categories are then marked according to the category related to them.

Finally, visual content, considered as documentary data, was analysed using the same pattern of analysis as before by categorising the results based on themes (Ritchie et al., 2014). As a first step, the advert issued by the company as part of their marketing campaign was analysed as it was very important to address the meaning behind that advertisement. According to Scott (1990), meaning is defined as a criterion to test the clarity and comprehensibility of the visual content. Two different feedbacks were obtained from a mid-age male and a female in relation to this advertisement. Both agreed on the three main points that the company wanted to express with this advert, which are, the emotional side, the quality of the products and the engagement of the company with people's happiness. The method of analysing the content followed the semiotic analysis technique which refers to the process of analysing symbols based on the signs. Each sign contains two main elements, the signifier and the signified. The signifier is the recognisable song or picture that attracts our attention and the signified refers to the message and the idea itself (Bryman \& Bell, 2015, p. 570).

\subsection{Data Triangulation}

Data triangulation is defined as using different kinds of measures in order to increase the confidence in the accuracy of the observations (Easterby-Smith et al., 2015). According to Denzin (1978) the type of triangulation used for this study is methodological triangulation, where data is collected through multiple methods, as cited in Cox and Hassard (2005). In addition, it shows the social phenomenon studied in a rich and a complex picture (Mathison, 1988). For this study and in order to reduce the researcher's individual view on the data it was suggested to triangulate the data by collecting both secondary and primary data to increase the level of accuracy of the results.

\section{Analysis and Discussion}

\subsection{Analysis of Visual Contents and Written Documents}

In this part the discussion will associate each communicated message (visual or written) separately with its appropriate strategy from image repair theory. The discussion will also include sales figures and a chart showing the VW shares performance. Before starting the discussion, it is important to address that VW works in balance in their publishing press releases (PR) related to the scandal and other news related to the company. Although the event was very serious, it did not affect the public relations strategy. The figures below show the number of press releases related to the scandal as a percentage of the total number of press releases for the period between September 2015 and June 2016. 
Table 1. Number of press releases related to the scandal compared to total communications

\begin{tabular}{llll}
\hline Month & Total PR & PR related to scandal & $\%$ of the scandal related PR \\
\hline Sep/2015 & 14 & 10 & $71 \%$ \\
Oct/2015 & 46 & 11 & $24 \%$ \\
Nov/2015 & 41 & 11 & $27 \%$ \\
Dec/2015 & 32 & 3 & $9 \%$ \\
Jan/2016 & 36 & 0 & $0 \%$ \\
Feb/2016 & 34 & 1 & $3 \%$ \\
Mar/2016 & 41 & 0 & $0 \%$ \\
Apr/2016 & 37 & 3 & $8 \%$ \\
May/2016 & 26 & 0 & $0 \%$ \\
Jun/2016 & 29 & 3 & $10 \%$ \\
\hline
\end{tabular}

1) In the early days of the scandal between the 18th and the 23rd of September 2015, many news items and stories were published on all media channels. VW did not respond to the first day's negative press until the 21 st September. The company then admitted the cheating in the US but not in Europe. On Wednesday the 23rd September the CEO of the company, Martin Winterkorn, has resigned and the company released the board members' meeting conclusion in which they showed extreme efforts they had made to overcome the issue and to regain stakeholders' trust. With statements such as "The Executive Committee takes this matter extremely seriously". "The Executive Committee recognizes not only the economic damage caused, but also the loss of trust among many customers worldwide". "The Executive Committee agrees that these incidents need to be clarified with great conviction and that mistakes are corrected". "The Executive Committee is adamant that it will take the necessary decisive steps to ensure a credible new beginning". At this stage it is assumed that they were mortifying the issue and deciding on some corrective actions.

2) By hiring BP's oil spill lawyers, the company started to show their high level of commitment to their internal and external stakeholders, especially, employees, shareholders and retailers. Considering this as a corrective action, this type of message was intended to target these groups putting in mind that customers had little involvement in the case in court. With statements such as "Kirkland (the name of the law firm) will offer VW some much-needed assistance as it gears up for legal battles on both sides of the Atlantic. The law firm led BP's defence in the criminal court". This shows how seriously VW was taking this issue.

3) Two weeks later, VW initiated a marketing campaign entitled "We have broken the most important part of our cars: Your trust". This campaign mainly targeted at customers, because they had started to question what will happen to their cars and what would be the resale value (such questions were also highlighted by the interviewee as he manages a VW brand-new cars showroom). This campaign included many marketing activities i.e., social media posts, YouTube videos, TV advertisements, and the redevelopment of showrooms and services. The main purpose was to reduce the negative impact by admitting the company's mistake and by offering solutions, such as the website link which any owner of a VW car could access in order to check whether his/her car had the defective part.

4) An advert on YouTube was released on the 4th of February 2016 and this has been selected for analysis. The video was posted on three official accounts of VW, which were, the main account of the company, the UK account and France account on YouTube. The main objective of the advert was to use the technique of relationship marketing. "Relationship marketing refers to all marketing activities directed toward establishing, developing, and maintaining successful relational exchanges" (Morgan \& Hunt, 1994, p. 22). The advert was named "Companion", which is defined as, "a person or animal with whom one spends a lot of time or with whom one travels" (Oxforddictionaries.com). The analysis of this advert is divided into three main categories, firstly: emotional interactions category, here the company attempted to emphasise the role that it plays in every stage of people's lives, starting from childhood, youth, marriage and having children. The background song was also attractive and matched the visual content. The song was (I'll be your home) which was performed by the guitarists "Phillip LaRue". In addition, the advert showed the intimate eye contact between couples and children. Secondly, is the practical category, which can be seen from the vertical movements of the new cars coming out of the old ones. The advert began with the original Beetle (1960s) and finished with their latest model, the new Tauareq (SUV model). This signified that the company wanted to demonstrate that their cars are consistently the same in terms of quality and applicability. The final category was the logical category, in which they chose a highly impactful term to call the advertisement namely, 'Companion'. They wanted to demonstrate the strong link between customers and their valued cars. 
5) In late April 2016, most newspaper articles and TV news announcements revolved around the agreement between VW and the US authorities to buy back almost 500,000 cars which had had the defective part installed. The company was under a huge pressure from all parties, mainly authorities and stakeholders. This particular news has two sides. First, it showed the company was working hard with the authorities to overcome this issue. However, this type of news usually works as an indicator to the market and to investors to check the response of stakeholders before applying any of these actions. Second, it is about keeping the customers satisfied by showing the company is prepared to compensate any person who was affected by this scandal. As a result, this type of news is categorised as a reduction of offensiveness and corrective action strategies, by which the company is financially capable to obey any decision made by the authority.

6) Five days later, on the 28th of April 2016 VW published its annual report for 2015 which included the CEO's message to stakeholders. His message contained many references to the emissions issue and how the company was attempting to deal with the situation quickly and properly. The message included phrases such as: "We are doing everything we can to overcome this crisis" and "the diesel issue has clearly overshadowed much in recent weeks". Such phrases make it very clear that the company saw this issue as a high priority and they were working to solve it for the sake of retaining investors. Besides that, the message highlighted that this year-2016-is a year of transition in terms of "becoming faster and efficient, more flexible and courageous, more technically progressive and sustainable in all relevant aspects". He called all stakeholders to take part in this transition to achieve success at the end. The CEO statement included "2016 will clearly be a year of transition, a year when we lay the foundations for the future. I'm firmly convinced that, with time, we will be able to say: no matter how grave the crisis was, it also opened doors for us". As a result, it seems very clear that Muller, the CEO of the group, is mortified and attempting to reduce the offensiveness by shining light on each one's responsibility to help the company bounce back and by taking corrective actions to overcome the event. Regardless who wrote the statement, the CEO message reveals some of the new approach that the company is going to apply in the future.

7) As one of their corrective actions, the company's CEO launched the biggest change in the company's 10 years strategy. The strategy included major changes in several areas. The CEO also emphasised the need to overcome this unfortunate event by aiming to accomplish all the required recalls and engine repairs by early 2017 . The strategy is called the "2025 strategy" with an objective for the group to become an integral part of the modern transportation industry. Such messages build more trust and confidence that the group of executives are working very hard together to develop and improve and to overcome the scandal.

8) By the 28th of June 2016, a decision was made by the authorities and the company was asked to pay almost $\$ 15$ billion to buy back all defective cars. The announcement aired on all communication channels and it is assumed it had an impact on all stakeholders. To start with, a positive impact on customers due to the corrective measures taken by the company. Moreover, investors and retailers also agreed with this action and it helped a little in regaining their trust. According to the interviewee who manages a VW brand-new cars retail showroom, "it is good to reach a decision where no place for more expectations". He continued "we all are to work hard in rebuilding the brand integrity with customers as well as investors". This is considered a corrective action strategy. What strengthens the company's position is that they had already set aside an amount of $\$ 18$ billion for any repairs and fines which were set by the authorities.

The summary table below has been produced to summarise the most influential press releases made by the company in the post-scandal period. It includes a column showing a pattern indicating a relationship of the press release on the share price of the company in response to the action taken by the company. Some of these activities were communicated through the company's website, others were in the majority of the newspapers and on business news programmes on TV. 
Table 2. The relationship of press releases on VW's share price

\begin{tabular}{|c|c|c|c|c|c|}
\hline Date of the message & News & Communication Spread & Strategy & Impact on & Share Price +/- \\
\hline $18-23 / 09 / 2015$ & $\begin{array}{l}\text { News about cheating } \\
\& \text { admission of } \\
\text { Cheating }\end{array}$ & $\begin{array}{l}\text { News posts, TV, and } \\
\text { social media }\end{array}$ & $\begin{array}{l}\text { Mortification, } \\
\text { Corrective Actions \& } \\
\text { Reducing the } \\
\text { offensiveness }\end{array}$ & $\begin{array}{l}\text { All Stakeholders, i.e., } \\
\text { employees, retailers, } \\
\text { shareholders \& } \\
\text { customers }\end{array}$ & (-) $32 \%$ \\
\hline $23 / 09 / 2015$ & $\begin{array}{l}\text { Hired BP oil spill } \\
\text { lawyers }\end{array}$ & News posts, TV & Corrective Actions & $\begin{array}{l}\text { Mainly retailers \& } \\
\text { shareholders }\end{array}$ & (+) $5 \%$ \\
\hline 09/10/2015 & $\begin{array}{l}\text { Campaign starts - We } \\
\text { have broken your trust }\end{array}$ & $\begin{array}{l}\text { Company's website \& } \\
\text { other social media tools }\end{array}$ & $\begin{array}{l}\text { Reducing the } \\
\text { offensiveness \& } \\
\text { Corrective Actions }\end{array}$ & Mainly customers & $(+) 20 \%$ \\
\hline $21 / 04 / 2016$ & $\begin{array}{l}\text { Cars buy back } \\
\text { agreement in the USA }\end{array}$ & News posts, TV & $\begin{array}{l}\text { Reducing } \\
\text { offensiveness and } \\
\text { corrective actions }\end{array}$ & All Stakeholders & $(+) 10 \%$ \\
\hline $28 / 04 / 2016$ & $\begin{array}{l}\text { Publishing the annual } \\
\text { report includes CEO } \\
\text { message to } \\
\text { shareholders }\end{array}$ & $\begin{array}{l}\text { Company's website \& } \\
\text { other social media tools }\end{array}$ & $\begin{array}{l}\text { Mortification, } \\
\text { Corrective Actions \& } \\
\text { Reducing the } \\
\text { offensiveness }\end{array}$ & $\begin{array}{l}\text { Mainly shareholders \& } \\
\text { retailers }\end{array}$ & (+) $4 \%$ \\
\hline $27 / 06 / 2015$ & Payment of $\$ 15$ billion & $\begin{array}{l}\text { News posts, } \mathrm{TV} \text {, and } \\
\text { social media }\end{array}$ & Corrective actions & All Stakeholders & (-) $11 \%$ \\
\hline
\end{tabular}

Monthly sales figures show uncertainty and it is clear that the brand reputation has not yet recovered. These figures below are in comparison to the previous year's sales figures in the United Kingdom and the United States separately:

Table 3. Monthly sales data for Volkswagen cars in UK, Source: www.smmt.co.uk

\begin{tabular}{llllll}
\hline & \multicolumn{2}{l}{ Volkswagen UK } & \multirow{2}{*}{ \% Change } \\
\cline { 2 - 5 } Month & Current Year & \% Market share & Y2Y Comparison & \% Market share & \\
\hline Aug-15 & 7,611 & 9.63 & 6,127 & 8.49 & 24.22 \\
Sep-15 & 39,263 & 8.49 & 37,852 & 8.89 & 3.73 \\
Oct-15 & 13,970 & 7.86 & 15,495 & 8.62 & -9.84 \\
Nov-15 & 12,958 & 7.24 & 16,196 & 9.40 & -19.99 \\
Dec-15 & 14,415 & 8.00 & 14,475 & 8.71 & -0.41 \\
Jan-16 & 12,055 & 7.10 & 13,993 & 8.49 & -13.85 \\
Feb-16 & 6,694 & 8.03 & 7,710 & 10.02 & -13.18 \\
Mar-16 & 38,694 & 7.46 & 38,685 & 7.85 & 0.02 \\
Apr-16 & 16,877 & 8.91 & 18,690 & 10.06 & -9.70 \\
May-06 & 16,050 & 7.88 & 17,316 & 8.71 & -7.31 \\
Jun-16 & 19,196 & 7.51 & 23,670 & 9.18 & -18.90 \\
\hline
\end{tabular}

Table 4. Monthly sales data for Volkswagen cars in USA, Source: http://media.vw.com/

\begin{tabular}{llll}
\hline & \multicolumn{2}{l}{ Volkswagen USA } & Change in \% \\
\cline { 2 - 3 } Month & Current Year & Y2Y Comparison & \\
\hline Aug-15 & 32,332 & 35,181 & $-8.10 \%$ \\
Sep-15 & 26,141 & 25,996 & $0.56 \%$ \\
Oct-15 & 30,387 & 30,313 & $0.24 \%$ \\
Nov-15 & 23,882 & 31,725 & $-24.72 \%$ \\
Dec-15 & 30,956 & 34,058 & $-9.11 \%$ \\
Jan-16 & 20,079 & 23,504 & $-14.57 \%$ \\
Feb-16 & 22,321 & 25,710 & $-13.18 \%$ \\
Mar-16 & 26,914 & 30,025 & $-10.36 \%$ \\
Apr-16 & 27,112 & 30,009 & $-9.65 \%$ \\
May-06 & 28,779 & 34,758 & $-17.20 \%$ \\
Jun-16 & 23,809 & 30,436 & $-21.77 \%$ \\
\hline
\end{tabular}




\subsection{Analysis of the Interview}

As has been highlighted above, an interview was conducted with a manager of a brand-new cars dealer. The main objective of this was to increase the level of accuracy when interpreting the above documents and stock price chart. The interview took place in United Kingdom with a manager of one of VW's brand-new car showroom. Some important points he raised were:

1) The impact was massive on VW, the emission issue hit almost all stakeholders of the company. For instance, the negative press comments, the fall in customers' confidence, and the impact on team morale. This led the company to make a huge change in its future outlook.

2) When a wrong action has been taken and the mistake is admitted by an organisation, it is very common for the head of the organisation to resign. The interviewee continued someone had to carry the blame and leaders usually pay the price.

3) Apart from the resale value of the cars, customers who visit the showrooms do not ask for more details about the emission issue. In addition, VW customers seem to be very loyal to the brand, they understand the issue and they are only concerned about ensuring that the defective part in their car is replaced.

4) Customers are fully aware of the marketing communication activities taken by the company in the post-emission period. It increased their commitment to the brand and it helped in resolving the issue. Compared to Toyota's safety issue - as the interviewee has experience of them - he illustrated that VW handled the case properly from the early days although Toyota's officials did not react to their safety issue quickly. The press attacked Toyota and they found themselves blamed and they needed to take defensive actions. One example of this was Toyota's CEO admission and apologies in front of the members of congress in the US.

5) All VW dealers are aware of all the marketing activities carried out by VW and they have an online portal to share this.

6) The interviewee thinks that the model which VW implemented to respond to the emission issue was the correct one. He stressed that the early announcement of the issue by VW and then the company's admission of that fault was also correct. In addition, their promise to repair and buy back all affected cars had an excellent positive impact on customers' trust. All these examples show a high response level from the company to protect their reputation and to regain the broken trust.

7) The company is making a significant development in all aspects, refurbishing stores, re-building the lost brand trust, re-installing affected cars the proper parts needed, and increasing investors' trust. These investors are not only shareholders, there are many other investors such as, retailers who deal with $\mathrm{VW}$, manufacturers, as well as financiers.

\subsection{Linking the Findings to the Case of Volkswagen's Scandal}

Before starting the discussion, it is important to address the fact that the scandal did not fear the life of people as happened with Toyota in 2010. In the VW case, the conflict appeared to be more with the authorities and the value of the cars. It is also important to note that strong brands are less likely to be affected by negative publicity compared to weak brands (Hsu \& Lawrence, 2015).

Firstly, the company and its public relations department were fairly successful in applying several of the image repair strategies. They mainly focused on mortification, corrective actions and reducing the offensiveness by using transcendence and compensation. The timing and objective of each message was also selected properly and effectively. The press releases seemed to be well planned in terms of quantity and content. All selected messages from the list above seem to have an objective behind it. In addition, it is clear that minimising the number of messages related to the scandal month after month was also planned.

Secondly, the share price was not a good predictor of the impact of the message because it was uncertain. The major result according to the chart of the company is that they were trying to minimise the impact on the investor and regain the trust. What indicates a relationship could be the moderate climb of the share price week after week until it reached almost $\$ 140$ from the lowest value after the scandal announcement, which was $\$ 101$.

Finally, investors have shown a positive discourse with the communication strategies applied by the company. This can clearly be seen from the positive share price figures and the dealer's comments. However, customers seem to be quite far to believe whatever published after the scandal. It is also believed it will need much more time to rebuild the trust. Sales figures could be a good indicator of customers' level of trust. 


\subsection{Answers to the Research Questions}

1) Answer to RQ1:

VW implemented two main marketing strategies which were, relationship marketing and brand loyalty. In addition, they used mainly three main strategies from image repair theory to respond to the offensive published news. These strategies were, reducing the offensiveness in particular (transcendence and compensation), corrective actions and mortification.

\section{2) Answer to RQ2:}

The market response to the marketing communication activities taken by VW in the post-emission scandal is still not clear. However, the share price of the company was rising gradually and the price range was between $\$ 130$ and $\$ 140$ compared to the lowest price after the scandal which was $\$ 102$. The price before the announcement was in the range of $\$ 170$ to $\$ 190$ (Bloomberg.com). Furthermore, monthly sales reports show negative sales figures in comparison to the same month in the previous year (Table 2) and (Table 3).

\section{3) Answer to RQ3:}

Many advantages could be highlighted from the model which VW used in their scandal communication. Firstly, mortification, the CEO expressed his admission and regrets to all stakeholders and this usually leads to more transparency in the relationship between stakeholders and the company. Secondly, corrective actions, were the company at the beginning put aside a huge budget to overcome this event. By doing this action the company showed that it is financially capable to reduce the drawbacks from this scandal. Finally, reducing offensiveness, the public relation team managed to reduce the number of press releases related to the scandal gradually and they fairly succeeded in that. In addition, they left the attention of all stakeholders towards the new strategy which the new CEO announced. As a result, they manage to re gain some trust from all stakeholders externally and internally.

From the other hand, the company spend less efforts in denying the act partially. They could of share the blame between the company and the authority in which they could argue the reasons behind the authorities giving them the green light to passing cars with the defective part. They also could evade the responsibility as this issue happened accidentally by having less knowledge about the procedure carried on testing the level of emission. Finally, VW started to shift the attention of its stakeholders to other activities which can be seen from the audiences as focus into minor issues rather than solving the problems related to the scandal.

\section{4) Answer to RQ4:}

There is only one major change the company should do these days as number of press releases related to the scandal is already been reduced. They must put more focus on continue announcement about the scandal and their actions towards it. Some positive lessons that can be highlighted from their model are: VW targeted all stakeholders with at least one or two very influential messages. Secondly, they applied a proper strategie from image repair theory which helped them in gaining some trust back, these are, Mortification, reducing the offensiveness and corrective actions. Thirdly, the early announcement helped in reducing the number of wrong stories and rumors. Fourthly, the company implement a good relationship marketing tool in their advertisement and other marketing activities especially with customers. They worked on the emotional and good past intentions very well to remind customers that the company is still there and the quality of the products will never change. Finally, the technique of reducing the number of press releases related to the scandal is somewhat considered as a positive tactic, however, it is very important to not remove this issue from the public relation activities until the problem is totally solved and the consequences are totally recovered.

\section{Conclusion}

The answer as to whether or not VW is going to retain its brand image in the near future remains to be seen. It is almost certain that the company will experience an unstable period for some time to come. This study aimed to evaluate the effectiveness of the marketing communication strategy used by VW in the post-scandal period. Several types of data were used to examine this, and the triangulation technique was utilised to improve the accuracy and reduce bias in the analysis. Considering the communication strategy that was adopted by the company in the post-emission scandal period, it seems clear that VW did not use any of the denial and evasion of responsibility strategies. However, they did use reducing the offensiveness, corrective actions and mortifications in their response to all stakeholders. In comparison, in a similar case, BP tried to implement a less effective public relations strategy by trying to turn attention to their efforts to resolve the problem and their compensations scheme (Harlow \& Harlow, 2013). This to some extent can be less effective, because when a crisis hits, the two main issues to focus on are the target audience and trying to balance between your offensive and defensive 
stance. VW, on the other hand, tried to balance between solving the issue with the authorities, announcing their managerial decisions in parallel with executing a marketing communication plan, which to some extent was effective in terms of saving the company's brand reputation.

To obtain a more complete picture, this study should be continued as it covers only the first ten months after the scandal. The data were collected between 18th of September, 2015 and 30th of June 2016, which helped in addressing the early response to the scandal. It is believed that some further issues related to the scandal may appear in the near future. In addition, the consequences of such an event will be felt for quite some time to come.

\subsection{Limitations of the Study}

Three limitations to this research can be highlighted. Firstly, it is strongly suggested that another study be conducted to compare the findings and to give more strength to the results, for example, Toyota's crisis or British Petroleum oil spill scandal. Secondly, as mentioned above, case studies have three main limitations, these are: a lack of transparency, sampling and researcher reflection on the research. In this study, the process of selecting and analysing data was somewhat ideal and the researcher tried to reduce the level of bias by triangulating the results but this issue still remains in question. Sales data were only found for the United Kingdom and the United States, so it is very important to obtain the total worldwide sales figures in order to come to a conclusion about the impact of the scandal in general as all other data concerned the overall impact on the company. Finally, it was planned to obtain at least two samples of feedback from practitioners such as retailers or manufactures who have a strong business link with VW. However, due to limited time and access, it was not possible to reach more participants.

\section{References}

Benort, W., \& Czerwinski, A. (1997). A Critical Analysis of USAi's Image Repair Discourse. Business Communication Quarterly, 60, 38-57. https://doi.org/10.1177/108056999706000304

Benoit, W. L. (1995). Accounts, Excuses, and Apologies: A Theory of Image Restoration Strategies. State University of New York Press.

Benoit, W. L. (1997). Image Repair Discourse and Crisis Communication. Public Relations Review, 23, $177-186$. https://doi.org/10.1016/S0363-8111(97)90023-0

Benoit, W. L. (2014). Accounts, Excuses, and Apologies: Image Repair Theory and Research. SUNY Press.

Berman, B. (1999). Planning for the Inevitable Product Recall. Business Horizons, 42, 69-78. https://doi.org/10.1016/S0007-6813(99)80011-1

Bernstein, J. (2004). The 10 Steps of Crisis Communications. Crisis Response, prevention, planning and, Training, 106.

Bryman, A., \& Bell, E. (2015). Business Research Methods. Oxford: Oxford University Press.

Cleeren, K., Dekimpe, M. G., \& Helsen, K. (2008). Weathering Product-Harm Crises. Journal of the Academy of Marketing Science, 36, 262-270. https://doi.org/10.1007/s11747-007-0022-8

Companion Definition [Online]. (2016). Oxford Dictionaries. Retrieved April 6, 2016, from http://www.oxforddictionaries.com/definition/english/companion

Coombs, T., \& Schmidt, L. (2000). An Empirical Analysis of Image Restoration: Texaco's Racism Crisis. Journal of Public Relations Research, 12, 163-178. https://doi.org/10.1207/S1532754XJPRR1202_2

Coombs, W. (2012). Ongoing Crisis Communication: Planning, Managing, and Responding. London, SAGE Publication.

Coombs, W. T. (2007). Protecting Organization Reputations During a Crisis: The Development and Application of Situational Crisis Communication Theory. Corporate Reputation Review, 10, 163. https://doi.org/10.1057/palgrave.crr.1550049

Coombs, W. T. (2015). The Value of Communication during a Crisis: Insights from Strategic Communication Research. Business Horizons, 58, 141-148. https://doi.org/10.1016/j.bushor.2014.10.003

Coombs, W. T., \& Holladay, S. J. (2002). Helping Crisis Managers Protect Reputational Assets Initial Tests of the Situational Crisis Communication Theory. Management Communication Quarterly, 16, $165-186$. https://doi.org/10.1177/089331802237233

Coombs, W. T., \& Holladay, S. J. (2011). The Handbook of Crisis Communication. John Wiley \& Sons. 
Cox, J. W., \& Hassard, J. (2005). Triangulation in Organizational Research: a Re-presentation. Organization, 12 , 109-133. https://doi.org/10.1177/1350508405048579

Dawar, N., \& Pillutla, M. M. (2000). Impact of Product-Harm Crises on Brand Equity: The Moderating Role of Consumer Expectations. Journal of Marketing Research, 37, 215-226. https://doi.org/10.1509/jmkr.37.2.215.18729

Denzin, N. K. (1978). The Research Act: A Theoretical Introduction to Sociological Methods. New York, McGraw-Hill.

Dutta, S., \& Pullig, C. (2011). Effectiveness of Corporate Responses to Brand Crises: The Role of Crisis Type and Response Strategies. Journal of Business Research, 64, 1281-1287. https://doi.org/10.1016/j.jbusres.2011.01.013

Easterby-Smith, M., Thorpe, R., \& Jackson, P. R. (2015). Management and Business Research. SAGE Publications Ltd.

Fill, C. (2013). Marketing Communications: Brands, Experiences and Participation. Pearson.

Frank, D., \& Michel, M. H. (2009). Prescribing Versus Describing: Testing Image Restoration Strategies in a Crisis Situation. Corporate Communications: An International Journal, 14, 101-118. https://doi.org/10.1108/13563280910931108

Gardner, J. (2009). The Logic of Excuses and the Rationality of Emotions. The Journal of Value Inquiry, 43, 315-338. https://doi.org/10.1007/s10790-009-9181-9

Hall, R. (1992). The Strategic Analysis of Intangible Resources. Strategic Management Journal, 13, $135-144$. https://doi.org/10.1002/smj.4250130205

Harlow, W. F., Brantley, B. C., \& Harlow, R. M. (2011). BP Initial Image Repair Strategies after the Deepwater Horizon Spill. Public Relations Review, 37, 80-83. https://doi.org/10.1016/j.pubrev.2010.11.005

Harlow, W. F., \& Harlow, R. M. (2013). Compensation and Corrective Action as the BP Response to the Deepwater Horizon Incident. Communication Research Reports, 30, $193-200$. https://doi.org/10.1080/08824096.2013.806252

Helm, S., \& Tolsdorf, J. (2013). How Does Corporate Reputation Affect Customer Loyalty in a Corporate Crisis? Journal of Contingencies and Crisis Management, 21, 144-152. https://doi.org/10.1111/1468-5973.12020

Ho, B., Shin, W., \& Pang, A. (2016). Corporate Crisis Advertising: A Framework Examining the Use and Effects of Corporate Advertising before and after Crises. Journal of Marketing Communications, 1-15. https://doi.org/10.1080/13527266.2015.1136349

Holtzhausen, D., \& Roberts, G. (2009). An Investigation into the Role of Image Repair Theory in Strategic Conflict Management. Journal of Public Relations Research, 21, 165-186. https://doi.org/10.1080/10627260802557431

Hsu, L., \& Lawrence, B. (2015). The Role of Social Media and Brand Equity During a Product Recall Crisis: A Shareholder Value Perspective. International Journal of Research in Marketing, 33(1), 59-77. https://doi.org/10.1016/j.ijresmar.2015.04.004

Jory, S. R., Ngo, T. N., Wang, D., \& Saha, A. (2015). The Market Response to Corporate Scandals Involving CEOs. Applied Economics, 1-16. https://doi.org/10.1080/00036846.2014.995361

Kim, S. (2013). Does Corporate Advertising Work in a Crisis? An Examination of Inoculation Theory. Journal of Marketing Communications, 19, 293-305. https://doi.org/10.1080/13527266.2011.634430

Kim, S., \& Atkinson, L. J. (2014). Responses Toward Corporate Crisis and Corporate Advertising. Journal of Promotion Management, 20, 647-665. https://doi.org/10.1080/10496491.2014.946201

Kottasova, I. (2015). Volkswagen Sales Plunge on Emissions Scandal. CNN Money, 13/11/2015.

Kuckartz, U. A. (2014). Qualitative Text Analysis: A Guide to Methods, Practice \& Using Software. SAGE Publications Ltd. https://doi.org/10.4135/9781446288719

Laufer, D., \& Coombs, W. T. (2006). How Should a Company Respond to a Product Harm Crisis? The Role of Corporate Reputation and Consumer-Based Cues. Business Horizons, 49, $379-385$. https://doi.org/10.1016/j.bushor.2006.01.002 
Long, D., \& Rao, S. (1995). The Wealth Effects of Unethical Business Behavior. Journal of Economics and Finance, 19, 65-73. https://doi.org/10.1007/BF02920510

Mathison, S. (1988). Why Triangulate? Educational Researcher, 17, 13-17. https://doi.org/10.3102/0013189X017002013

Morgan, R. M., \& Hunt, S. D. (1994). The Commitment-Trust Theory of Relationship Marketing. Journal of Marketing, 58, 20-38. https://doi.org/10.2307/1252308

Pearse, W. H. (2010). Apologia. Women's Health Issues, 20(1), 2. https://doi.org/10.1016/j.whi.2009.10.005

Ritchie, J., Lewis, J., Mcnaughton, C. C., \& Ormston, R. (2014). Qualitative Research Practice: A Guide for Social Science Students and Researchers. SAGE Publications Ltd.

Ruddick, G. (2015). VW Emissions Scandal Widens to Include Porsche Claims. The Guardian, 02/11/2015.

Scott, J. (1990). A Matter of Record: Documentary Sources in Social Research. Cambridge: Polity Press.

Scott, M., \& Lyman, S. (1968). Accounts. American Sociological Review, 33, 46-62. https://doi.org/10.2307/2092239

Seeger, M. W., Sellnow, T. L., \& Ulmer, R. R. (2003). Communication and Organizational Crisis. Greenwood Publishing Group.

Tischer, S., \& Hildebrandt, L. (2014). Linking Corporate Reputation and Shareholder Value Using the Publication of Reputation Rankings. Journal of Business Research, 67, 1007-1017. https://doi.org/10.1016/j.jbusres.2013.08.007

Ulmer, R. R., Sellnow, T. L., \& Seeger, M. W. (2013). Effective Crisis Communication: Moving from Crisis to Opportunity. Sage Publications.

Valackiene, A. (2010). Efficient Corporate Communication: Decisions in Crisis Management. Inzineriné Ekonomika, 21, 99-110.

Walsh, G., Mitchell, V. W., Jackson, P. R., \& Beatty, S. E. (2009). Examining the Antecedents and Consequences of Corporate Reputation: A Customer Perspective. British Journal of Management, 20, 187-203. https://doi.org/10.1111/j.1467-8551.2007.00557.x

Yin, R. K. (2013). Case Study Research: Design and Methods. SAGE Publications Ltd.

\section{Copyrights}

Copyright for this article is retained by the author, with first publication rights granted to the journal.

This is an open-access article distributed under the terms and conditions of the Creative Commons Attribution license (http://creativecommons.org/licenses/by/4.0/). 